GOSPODARKA SUROWCAMI MINERALNYMI - MINERAL RESOURCES MANAGEMENT

2016 Volume $32 \quad$ Issue $4 \quad$ Pages $45-58$

DOI 10.1515/gospo-2016-0037

\title{
Metals in Spent Mobile Phones (SMP) - a new challenge for mineral resources management
}

\section{Introduction}

Urban mining is the area of economic activity, which uses a stream of municipal wastes related to the growth of the standard of living. This term was introduced by Michio Nanjo from Tohoku University in the 1980s (Willner, Fornalczyk 2012). Originally, the term urban mining was strictly related to waste electric \& electronic equipment (WEEEs), which contain relatively high concentrations of many metals, especially copper, nickel, gold, silver, platinum group metals, but also rare earth elements (REE), gallium, germanium, indium, tantalum, etc. WEEEs are still considered the backbone stream in urban mining as they contain many expensive metals, including those currently classified as critical raw materials (Cossu and Williams 2015). Such wastes, by their collection and modern processing, are the secondary source of many metals, supplementing or replacing supplies of such metals from primary sources - metal ores deposits (Nieć et al. 2014). Therefore, urban mining can be understood as the systematic, goal-oriented management of anthropogenic materials in urban areas, where end-of-life properly stored products (especially WEEEs, but also scrapped cars) can be an important source of metals, and places of their accumulation - treated as future urban mines.

It is worth mentioning that - in the case of WEEEs - the primary condition for urban mining development is their effective collection system, ease of their disassembly and de-

* Prof., Warsaw University, Faculty of Geology, Warsaw, Poland; e-mail: Krzysztof.Szamalek@uw.edu.pl

** D.Sc Eng., Associate Professor of MEERI PAS, Mineral and Energy Economy Research Institute,

Polish Academy of Sciences, Krakow, Poland; e-mail: krzysztof.galos@min-pan.krakow.pl 
velopment of appropriate processing technologies. However, the metals' concentration in such end-of-life products is many times higher than in metal ores, their receipt from such sources is significantly less energy intensive than production from metal ores, and also provides important environmental advantages. Therefore, the works similar to the "geological reconnaissance" are introduced to determine the potential of metals in the WEEEs (Mueller et al. 2015). The process of metal production from WEEEs has similar stages as production from mineral deposits (Fig. 1), starting from electric \& electronic equipment (EEE) consumers (equivalent of Earth crust) through the WEEE collection (equivalent of the metal ore deposit), separation (ore mining), concentration (ore enrichment) up to metals' smelting and refining (very similar or the same as smelting and refining of metals ore concentrates).

Such an approach is an important part of the sustainable development of the world economy, as e.g. projected accumulated consumption in the years 2000-2050 are close to the current level of ore reserves in deposits in the case of iron, molybdenum, tungsten, cobalt, platinum, palladium, several times higher than the current level of ore reserves in deposits in the case of nickel, manganese, lithium, indium and gallium, while many times higher than the current level of ore reserves in deposits (and even higher than the level of the reserve base) in the case of copper, lead, zinc, gold, silver and tin. Moreover, what is also important, just now in the case of some metals, on-surface stock is higher than underground stock (ore reserves), e.g. they constitute approx. $70 \%$ of all stock in the case of silver and gold, and almost 50\% in the case of copper (Halada 2008).

Mobile phones are in the group of the smallest EEEs. At present, approx. 4-5\% of world production of gold, silver and copper, as well as even up to $20 \%$ of world production of palladium and cobalt, are currently used for their production (Hageluken 2013). The disassembly of mobile phones is difficult, their life cycle is still getting shorter due to sharp technology development and specific race of mobile phones offers, giving ever newer, better and quicker models, with increasing IT services capabilities. The majority of mobile phones are decommissioned (currently on average after 18 months) not due to their obsolescence, damage or
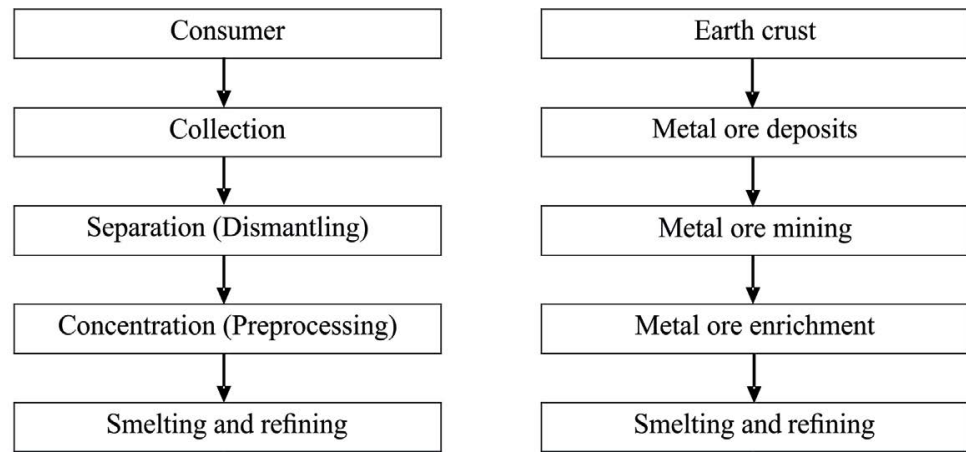

Fig. 1. Scheme of metals production from waste electric \& electronic equipment (WEEE) and from metal ore deposits (own work)

Rys. 1. Schemat produkcji metali ze zużytego sprzętu elektrycznego i elektronicznego (ZSEE) oraz ze złóż rud metali (opracowanie własne) 
inefficiency, but because of their replacement by new and better devices. As they are really small devices, they are very often stored or even disposed of with household waste (Buchert et al. 2012). It is very common that each person using mobile phones has 2, 3 or even more older devices "hidden in a drawer" (Fig. 2). This is why the mobile phone end-of-life recycling rates are still extremely low, commonly only several \%, while for other, larger WEEEs (e.g. PCs, laptops) these rates are much better. So, spent (end-of-life) mobile phones are very important, but still mostly unused, a secondary source of many metals. The potential of metal recovery from spent mobile phones (SMPs) and their conditions are analyzed in the paper.

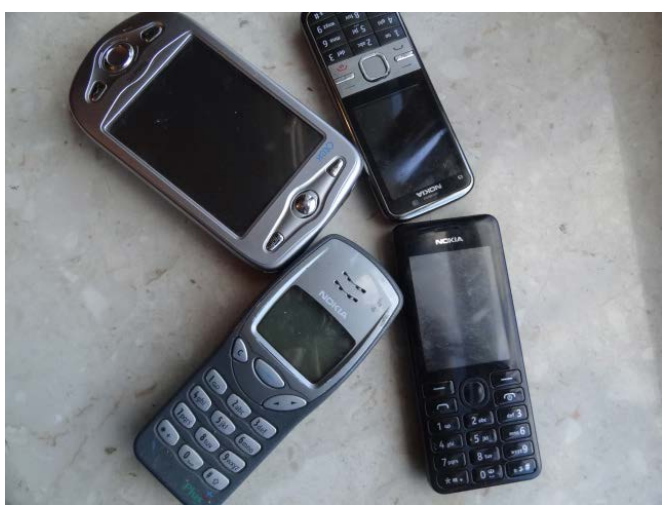

Fig. 2. Spent mobile phones hidden in a drawer of one of authors (photo K. Szamałek)

Rys. 2. Zużyte telefony komórkowe z szuflady jednego z autorów (fot. K. Szamałek)

\section{Estimation of the amounts of mobile phones being used and recycled in the world and in Poland}

Until recently, there was a lack of continuous reporting on mobile phone sales and mobile phones in use worldwide. Mobile phone sales rose from approx. 100 million units in 1997 to approx. 780 million units in 2005 (Sullivan 2006). In 2010, total number of sold mobile phones amounted to approx. 1.6 billion units, while - in comparison - of sold PCs/laptops approx. 350 million units (Bloodworth 2012). Recently, worldwide combined shipments for electronic devices (PCs, tablets, smartphones, other mobile phones) amounted to approx. 2.40 billion units in 2015 . They are expected to increase in 2016 by only $0.6 \%$ to 2.44 billion units, and reach total sales of approx. 2.55 billion units in 2018 (Gartner 2016). Among them, total mobile phone sales in 2015 amounted to 1.92 billion units, including 1.43 billion smartphone units (Gartner 2016; IDC 2015). Total mobile phone sales are expected to increase 
in 2016 by $1.3 \%$ to 1.94 billion units, and reach total sales of approx. 2.02 billion units in 2018 (Gartner 2016). Of them, smartphone sales are expected to increase in 2016 by $7 \%$ to 1.53 billion units, and reach total sales of approx. 1.78 billion units in 2018 and 1.86 billion units in 2019 (IDC 2015).

Further growth of their sales will be expected mostly out of the mature markets such as: North America, Europe, Japan and other mature Asia/Pacific countries. The above mentioned regions expect to see an extension of mobile phone lifetimes among users, as software becomes more complex and users are likely to hold onto phones, especially as the technology updates are becoming incremental rather than exponential. In addition, the volumes of users upgrading from basic mobile phones to smartphones will slow, as market will be saturated by smartphones (Gartner 2016).

The number of mobile phones in use worldwide amounted to approx. 1.0 billion units in 2002, while over 2.7 billion units in 2009 (Sullivan 2006; Bloodworth 2012). Currently, according to the best estimates, the number of mobile phones in use reached approx. 7 billion units, including 1.3 billion units in China, over 1.0 billion units in India, approx. 330 million units in the US, and over 200 million units in - each - Brazil, Russia and Indonesia (Wikipedia 2016). This is in good relation to worldwide mobile phone subscriptions, which amounted to 738 million in 2000 , but increased almost ten times within a 15 year period up to 7,300 million in 2015 (Ericsson 2016). In 2015, there were approx. 1,140 million mobile phone subscriptions in Europe, almost 1,300 million in China, approx. 1,030 million in India, approx. 1,820 million in other Asian countries, approx. 960 million in Africa, approx. 310 million in Latin America, and almost 400 million in North America (Ericsson 2016).

A large proportion of spent mobile phones (SMPs) and smartphones is not collected, being stored by the users over longer periods of time, so that delayed end-of-life management is expected. In addition, the ease with which such small devices can be binned plays a role in the improper disposal of these equipment into household waste (Buchert et al. 2012). If we assume that each current mobile phone user has at least 2 SMPs "hidden in a drawer", it gives an indicative amount of approx. 14 billion SMP units, which potentially could be recycled worldwide.

Information on the recycling of SMPs is very random. It was estimated that in 2003, only less than $1 \%$ of obsolete mobile phones were recycled worldwide (Sullivan 2006). In Germany, it was estimated that in 2007 approx. 2,273 $t$ of mobile phones became obsolete, of which only $110 \mathrm{t}$ were collected by official collection systems. This therefore meant that only approx. $5 \%$ of SMPs were sent to controlled recycling facilities this year, while the main metals, which were recovered, were: copper, gold, silver and palladium. Currently, it is difficult to expect that the collection rate of SMPs is higher than $10-15 \%$, even in the most developed countries (Buchert et al. 2012).

In Poland, total mobile phone sales in 2015 amounted to approx. 10.3 million units, including approx. 7.5 million smartphone units. Total mobile phone sales are expected to increase in 2016 by $2-3 \%$, but sales of smartphones by approx. 7\% (IDC 2016). The number of active 
SIM cards in Poland rose from 29.2 million units at the end of 2005 to 47.5 million units in 2010 and 56.2 million units at the end of 2015 (GUS 2016). It is expected that the number of mobile phones in use is slightly lower than that of active SIM cards, but probably exceeds 50 million units, including 15-20 million smartphones. If we assume that each current mobile phone user has at least 2 SMPs "hidden in a drawer", it gives an indicative amount of approx. 100 million SMP units, which could potentially be recycled in Poland, including up to 30 million spent smartphones. Until now, SMPs collection and processing in Poland is even lower than in other European countries. It is hard to expect that the rate of SMPs collection in Poland is higher than $1 \%$.

\section{Spent mobile phones (SMP) as a source of metals to be recycled}

Mobile phones contain numerous metals, including expensive ones. The most important are: copper, nickel, silver, gold, platinum group metals, cobalt, lithium, lead, tin, zinc, rare earth metals, gallium, indium, iron, chromium, niobium, tantalum, titanium. These most important parts of mobile phones, where these metals are used, are as follows:

- Copper - connectors, printed circuit boards, resistors, coils, speakers.

- Nickel - connectors, capacitors, resistors, shield plates, batteries.

- Silver - printed circuit boards, capacitors, resistors.

- Gold - connectors, printed circuit boards.

- Palladium - printed circuit board.

- Cobalt - batteries.

- Lithium - batteries.

- Lead - capacitors, resistors.

- Tin - printed circuit boards, capacitors, LCD displays.

Zinc-resistors.

- REE - permanent magnets, LCD displays, speakers.

- Gallium - printed circuit boards.

- Indium - LCD displays.

- Iron - resistors, shield plates.

- Chromium - shield plates.

- Niobium - printed circuit boards.

- Tantalum - printed circuit boards.

- Titanium - capacitors (Buchert et al. 2012; Halada 2008).

Information on the metals' content in mobile phones is very dispersed and incomplete. In 2005, a typical mobile phone's weight was $113 \mathrm{~g}$ (excluding batteries), with a $25 \%$ share of metals. The most important of them - in terms of weight - were: copper, iron, nickel, silver, and zinc, with smaller amounts of gold, lead, manganese, palladium, platinum, tin and others. So, in a typical mobile phone in 2005 the average copper content was approx. $16 \mathrm{~g}$, of silver - approx. $350 \mathrm{mg}$, of gold - approx. $34 \mathrm{mg}$, of palladium - approx. $15 \mathrm{mg}$. 
In other words, in $1 \mathrm{Mg}$ of SMP, the average copper content was $140 \mathrm{~kg}$, silver content $3.14 \mathrm{~kg}$, gold content $-0.30 \mathrm{~kg}$, palladium content $-0.13 \mathrm{~kg}$ (Sullivan 2006). According to a recent German study (Buchert et al. 2012) typical mobile phones contain approx. $250 \mathrm{mg}$ of silver, $24 \mathrm{mg}$ of gold, $9 \mathrm{mg}$ of palladium, $40 \mathrm{mg}$ of neodymium, $8 \mathrm{mg}$ of praseodymium, while typical smartphones $-305 \mathrm{mg}$ of silver, $30 \mathrm{mg}$ of gold, $11 \mathrm{mg}$ of palladium, $50 \mathrm{mg}$ of neodymium, $10 \mathrm{mg}$ of praseodymium. In relation to their weight, this means that in $1 \mathrm{Mg}$ of SMPs average contents of these metals were as follows: silver - approx. $2.78 \mathrm{~kg}$, gold $0.27 \mathrm{~kg}$, palladium $0.10 \mathrm{~kg}$, neodymium $0.45 \mathrm{~kg}$, praseodymium $0.09 \mathrm{~kg}$. Furthermore, recycling mobile phones and smartphones provide synergies from the potential recovery of other metals such as copper, lead, nickel, tin, etc. (Buchert et al. 2012).

It was estimated that in 2010, the total number of sold mobile phones worldwide amounted to approx. 1,600 million units, while approx. 350 million units of sold PCs/laptops. This equalled the total content of approx.: 189,000 $\mathrm{t}$ of copper, 17,800 $\mathrm{t}$ of cobalt, $750 \mathrm{t}$ of silver, $115 \mathrm{t}$ of gold, and $42 \mathrm{t}$ of palladium (Bloodworth 2012). In Germany alone, total amount of smartphones sold in 2010 amounted to approx. 7.7 million pieces. Selected metals' content in these smartphones were estimated as follows: $48.5 \mathrm{t}$ of cobalt, $2,350 \mathrm{~kg}$ of silver, $230 \mathrm{~kg}$ of gold, $85 \mathrm{~kg}$ of palladium, $385 \mathrm{~kg}$ of neodymium, and $77 \mathrm{~kg}$ of praseodymium (Buchert et al. 2012).

Metals' content in mobile phone batteries should be regarded in a separate way, as such batteries, due to their composition, should be processed in a separate technological line. In standard mobile phones the battery weights approx. $20 \mathrm{~g}$ with approx. $3.8 \mathrm{~g}$ of cobalt, while batteries in smartphones - approx. $33 \mathrm{~g}$ with approx. $6.3 \mathrm{~g}$ of cobalt (Buchert et al. 2012). Other important metals in such batteries are nickel and lithium.

Hence, according to the available data, in $1 \mathrm{Mg}$ of SMPs (without batteries), the average copper content is $140 \mathrm{~kg}$, silver - approx. $2.78 \mathrm{~kg}$, gold $0.27 \mathrm{~kg}$, palladium $0.10 \mathrm{~kg}$, neodymium $0,45 \mathrm{~kg}$, praseodymium $0,09 \mathrm{~kg}$. In $1 \mathrm{Mg}$ of SMP batteries, the average cobalt content is approx. $190 \mathrm{~kg}$, while the nickel content - probably even more. If we assume that there are approx. 14 billion SMP units worldwide, which could potentially be recycled, and that a half of them are smartphones (average weight without batteries approx. $110 \mathrm{~g}$, battery $33 \mathrm{~g}-\mathrm{Bu}-$ chert et al. 2012), while the rest - traditional mobile phones (average weight without batteries approx. $90 \mathrm{~g}$, battery $20 \mathrm{~g}$ ), it would give the amounts of selected metals "imprisoned" in such spent mobile phones presented in Table 1. If we would do a similar calculation for Poland only (estimation of approx. 100 million SMP units, including approx. 30 million spent smartphones), it would give the impressive amounts of selected metals "imprisoned" in such spent mobile phones in Poland (Table 1).

It is important to underline that the concentrations of many metals in SMPs are several dozen up to one hundred times higher than in natural ores containing these metals (Hageluken 2013). For example:

- Copper - its average content in spent mobile phones is approx. $14 \%$, i.e. over a dozen times higher than in typical extracted copper ore.

- Cobalt - its average content in spent mobile phones is approx. 19\%, i.e. almost one hundred times more than in typical Co bearing ore. 
Table 1. Estimated amounts of selected metals in spent mobile phones, worldwide and in Poland ${ }^{1}$

Tabela 1. Szacunkowe ilości wybranych metali w zużytych telefonach komórkowych na świecie i w Polsce ${ }^{1}$

\begin{tabular}{|l|r|r|c|}
\hline \multicolumn{1}{|c|}{ Item } & $\begin{array}{c}\text { Worldwide } \\
\text { SMP }\end{array}$ & $\begin{array}{c}\text { SMP } \\
\text { in Poland }\end{array}$ & $\begin{array}{c}\text { Yearly sold mobile } \\
\text { phone in Poland (2015) }\end{array}$ \\
\hline Estimated number of SMP [million units] & 14,000 & 100 & 10.3 \\
\hline • Including smartphones [million units] & 7,000 & 30 & 7.5 \\
\hline Total weight of SMP [Mg] & $1,400,000$ & 9,600 & 1,077 \\
\hline Copper [Mg] & 196,000 & 1,344 & 151 \\
\hline Silver $[\mathrm{Mg}]$ & 3,892 & 27 & 3.0 \\
\hline Gold $[\mathrm{Mg}]$ & 378 & 2.6 & 0.29 \\
\hline Palladium $[\mathrm{Mg}]$ & 140 & 1.0 & 0.11 \\
\hline Neodymium [Mg] & 630 & 4.3 & 0.48 \\
\hline Praseodymium [Mg] & 126 & 0.8 & 0.09 \\
\hline Total weight of spent batteries from SMP $[\mathrm{Mg}]$ & 371,000 & 2,390 & 304 \\
\hline Cobalt $[\mathrm{Mg}]$ & 70,490 & 454 & 58 \\
\hline
\end{tabular}

1 Assumptions: average weight without batteries - smartphone $110 \mathrm{~g}$, traditional mobile phone - $90 \mathrm{~g}$, weight of batteries - smartphone $33 \mathrm{~g}$, traditional mobile phone - $20 \mathrm{~g}$ (Buchert et al. 2012).

- Silver - its average content in spent mobile phones is approx. $2780 \mathrm{ppm}$, while in the richest parts of sole $\mathrm{Ag}$ or $\mathrm{Au}-\mathrm{Ag}$ ores silver contents are in hundreds ppm, while commonly at tens ppm.

- Gold - its average content in spent mobile phones is approx. $270 \mathrm{ppm}$, while in $\mathrm{Au}$ deposits it is commonly several ppm.

- Palladium - its average content in spent mobile phones is approx. 100 ppm, while in typical PGM ores it is up to 2-3 ppm (Bolewski ed. 1991-1994).

However, the basic challenge is how to accumulate millions of discarded end-of-life mobile phones into "urban mines" of economically viable size (Hageluken 2013).

When we regard single mobile phones, the value of the contained metals is not so impressive. For example, in 2008 in Japan the total value of metals in 1 mobile phone was estimated at approx. JPY 119 (equivalent toapprox. USD 1.2), including approx. JPY 96 per gold, almost JPY 6 per silver, JPY 5 per copper, over JPY 4 per palladium, JPY 4 per lead, and over JPY 2 per nickel (Halada 2008). In the USA in 2005, the total value of metals in 1 mobile phone was estimated at approx. USD 0.63 , including approx. USD 0.40 per gold, USD 0.13 per palladium, USD 0.06 per silver, USD 0.03 per copper (Sullivan 2006). Metal prices are changing, but even during the period of the highest precious and base metal prices (the years 2011-2013) their total value per mobile phone unit did not exceed USD 3/unit, while currently (September 2016) this value is probably under USD 2/unit. The majority (over 
$90 \%)$ of the metals' value in SMPs falls to precious metals, especially to gold (65-80\%). So, thanks to the high value of precious metals and their relatively high amounts, they are and will be an important driving force for the recycling of mobile phones and smartphones (Buchert et al. 2012).

\section{Technological and organizational issues related to recycling of metals from SMP}

Spent mobile phones (SMPs) are a part of waste electric \& electronic equipment (WEEEs), together with e.g. spent PCs, notebooks, laptops, tablets, LCD displays, flat screens, LED lights, etc. As they are the smallest devices from among those mentioned above, they are very often "hidden in a drawer" or even disposed of with household waste (Buchert et al. 2012). This is why mobile the phone end-of-life recycling rates are still extremely low, in the best cases achieving 10-15\%, while these rates are several times better for other WEEEs.

To make it efficient, SMP recycling needs to be a chain process, not a single process. Total recycling efficiency depends on the recovery rate at each step of the recycling process, i.e.: collection, dismantling, preprocessing and processing (smelting and refining). When the recovery rate at some step is low, total recycling efficiency is also low. When we take an example of precious metals' recovery from WEEEs in Western Europe, it can be estimated that their average recovery rate at dismantling is approx. $90 \%$, at preprocessing - approx. $60 \%$, at smelting and refining - approx. $95 \%$, while at the collection stage - only $30 \%$. This is why in such a case the total recycling efficiency is only at approx. 15\% (Hageluken 2013).

The process of metals' recovery from WEEE (including spent mobile phones) resembles an inverted pyramid. In the case of all of Europe, there should be tens of thousands of collection points, thousands of dismantling plants, hundreds of preprocessing plants and only several metallurgical plants, where pure metals are obtained (Hageluken 2013).

During the recycling of mobile phones and smartphones it is important to remove cobalt-containing lithium-ion batteries in order to send these separately to suitable battery recycling plants. The remaining parts are commonly milled together, then unmilled plastic or metal shells are separated and a powder rich in $\mathrm{Cu}, \mathrm{Au}, \mathrm{Ag}, \mathrm{Pd}, \mathrm{Ni}$ is obtained (it is sometimes called urban concentrate). This kind of charge is normally fed into pyrometallurgical plants. This processing primarily recovers high yields of metals such as copper, lead, nickel, tin and precious metals - gold, silver, palladium (Buchert et al. 2012; Hageluken 2013).

The most important optimization potential in the recycling chain for mobile phones and smartphones is clearly to raise the currently very low collection rate (commonly only several \%). On the contrary, pyrometallurgical recycling processes allow copper and precious metals at to be recovered at rates of $95 \%$ or more. There are also equally efficient processes for recovering cobalt from batteries. For other metals used for mobile phones production, there is still a need for basic research on the quantities involved and on the issue of whether these metals can be recovered at reasonable expenses despite the probable low contents and 
low absolute quantities (Buchert et al. 2012). Nevertheless, these trials are quite successful, e.g. the Umicore plant in Hoboken (see below).

Europe is home to leading companies recovering copper and precious metals from parts of various WEEEs (including mobile phones) in state-of-the-art plants. The most important of them are: the Hoboken plant of Belgian company Umicore with a throughput over 350,000 tpy, the Lünen plant of German company Aurubis with a throughput 350,000 tpy, the Rönnskar plant of Swedish company Boliden with a throughput of 120,000 tpy. Various WEEEs are processed there, including catalytic converters, printed circuit boards, mobile phones and smartphones, as well as industrial intermediate products and residues, slag, fly ash etc., using a complex pyrometallurgical process, with copper smelting and electro-refining, the recovering of precious metals from anode slime, lead recovery from slag in the blast furnace and further refining, recovery of other metals in separate refinery units. The leading example is Umicore's integrated smelter and refinery in Hoboken near Antwerp, where approx. 20 metals are recovered:gold, silver, platinum, palladium, rhodium, ruthenium, iridium, copper, lead, nickel, tin, antimony, bismuth, selenium, tellurium, indium, gallium (Buchert et al. 2012; Hageluken 2013).

There are also established recycling processes for cobalt and nickel from a range of WEEEs. For example in 2011, the Belgian company Umicore opened a pyrometallurgical plant in Hoboken with a capacity of 7,000 tpy of lithium-ion batteries and nickel hydride batteries. At present, it handles batteries from: notebooks, mobile phones and power tools. A cobalt/nickel/copper alloy is obtained from smelting process, which is processed in the Olen refinery to obtain pure nickel and cobalt salts for reuse in new batteries (Buchert et al. 2012).

\section{Towards improvement of metals' recovery from SMPs}

The topic of various metals' content in mobile phones, as well as the ways of their recycling from SMPs is still poorly recognized. The paper gives a very rough estimation for the entire world, as well as for Poland only. Worldwide, copper "imprisoned" in such spent mobile phones was estimated at almost $200,000 \mathrm{Mg}$ (i.e. approx. $1 \%$ of annual copper production), silver at almost $4,000 \mathrm{Mg}$ (approx. $12 \%$ of annual silver production), gold at almost $380 \mathrm{Mg}$ ( $9 \%$ of annual gold production), palladium at $140 \mathrm{Mg}$ (almost $70 \%$ of annual palladium production), cobalt at approx. $70,500 \mathrm{Mg}$ (over $80 \%$ of annual cobalt production) (Smakowski et al. eds. 2015). In Poland, these amounts are much less significant, though in the case of gold and palladium they are several times higher than official domestic consumption, while in case of cobalt - even ten times higher than domestic consumption (Smakowski et al. eds. 2015).

Still rising amounts of spent (end-of-life) mobile phones, as well as their still very poor collection rate are the main reasons of a very low recovery rate of metals from mobile phones, rarely exceeding $10 \%$. Hence, apart from technological solutions, one of the most im- 


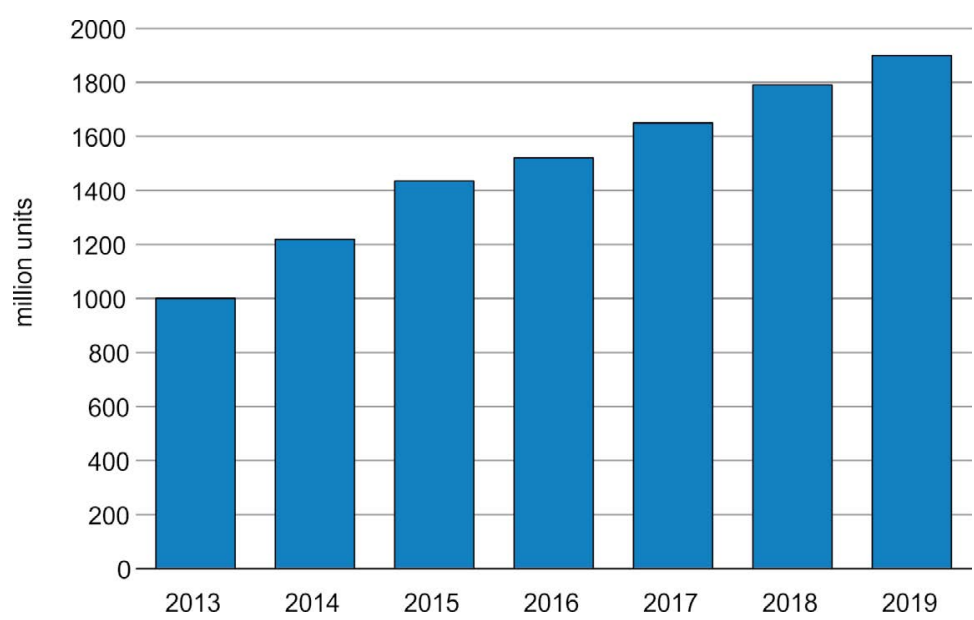

Fig. 3. Sales of smartphones, worldwide, with prognosis (Canalys 2016)

Rys. 3. Sprzedaż smartfonów na świecie, z prognozą (Canalys 2016)

portant challenges is the organization of effective SMP collections. Both legal and organizational solutions should be introduced here.

Regarding legal issues, until now, according to the former Act on WEEE of July 29, 2005 (Act on WEEE 2005), SMPs were classified into Group 3 "IT and telecommunication devices". For such a wide group, the minimal rate of collection is currently $40 \%$, the minimal rate of dismantling $-70 \%$, and the minimal rate of processing $-80 \%$. In 2015 , rate of collection for this group was quite high amounting 44.4\% (MIEP 2016; Pietrzyk-Sokulska 2016). This was thanks to the fact, that such large spent devices as PCs, notebooks, LCD displays are in this group. In 2015, a new Act on WEEE was enacted (Act on WEEE 2015). In this Act, SMPs were classified into Group 6 "Small IT and telecommunication devices - each dimension less than $50 \mathrm{~cm}$ ". Such a group will include only mobile phones, notebooks and laptops, printers, stationary phones, routers, calculators and GPS devices. Reporting for new groups, including Group 6, will be obligatory as of 2018. In the years 2018-2020, for Group 6, the minimal rate of collection will be $40 \%$, the minimal rate of dismantling $-55 \%$, and the minimal rate of processing $-70 \%$, while as of 2021 - the minimal collection will increase to $65 \%$. This should be a good step towards increasing the of recycling of metals from SMPs, though it will be hard to achieve such a high collection rate $-65 \%$ as of 2021 .

Certain organizational solutions should be introduced for such purposes. Firstly, mobile operators should introduce a mandatory rule that when a customer prolongs their service agreement with the operator, obtaining a new mobile phone, they are obliged to return their SMP, if they want to receive a new one. In such cases, other instruments used in environmental management can also be considered, such as product fees or ecological deposits. Moreover, some extra actions could also be proposed for a large amount of SMPs "hidden in a drawer" (e.g. by mobile operators) to attract people to bring in such spent devices, 
e.g. proposal of extra discounts on certain mobile services. Such examples have tried to be introduced in some developed countries, firstly in Japan. It is a good opportunity for the success of such actions taking the fact that a large part of such SMPs is located in urban areas, not in dispersed villages, into account.

\section{Conclusions}

1. Waste electric \& electronic equipment (WEEE), including spent mobile phones (SMPs), are huge potential source of metals such as: copper, silver, gold, palladium, platinum, REEs, tantalum, neodymium, indium and yttrium. The majority (over 90\%) of the metals' value in spent mobile phones falls to precious metals, especially to gold (65-80\%).

2. The estimated amount of SMPs "hidden in a drawer" in Poland is about 100 million units, including up to 30 million spent smartphones. In comparison, the total amount of worldwide SMPs is estimated at approx. 14 billion units to be recycled.

3. Metals' concentrations in SMPs is many times higher than metal concentrations in primary mineral deposits. Therefore, metal recovery from SMPs allows mining output to be decreased, which is environmentally friendly.

4. Metals included in SMPs "hidden in drawer" in Poland are estimated as follows: $\mathrm{Cu}-1,344 \mathrm{Mg}, \mathrm{Ag}-27 \mathrm{Mg}, \mathrm{Au}-2.6 \mathrm{Mg}, \mathrm{Pd}-1.0 \mathrm{Mg}, \mathrm{Nd}-4.3 \mathrm{Mg}, \mathrm{Pr}-0.8 \mathrm{Mg}$, $\mathrm{Co}-454 \mathrm{Mg}$.

5. It is necessary to introduce effective SMP collecting systems, as the current level of SMPs collection in Poland does not exceed 1\%. Therefore, mobile phones operators should introduce a mandatory rule that customers must return spent mobile phone when obtaining a new one.

6. There is an urgent need to fund the development of research on metal recovery from SMPs and similar spent devices in Poland.

\section{REFERENCES}

Act on WEEE 2005 - Act on Waste electric \& electronic equipment of July 292005 (Dz.U.2005.180.1495) (in Polish).

Act on WEEE 2015 - Act on Waste electric \& electronic equipment of September 112015 (Dz.U.2015.1688) (in Polish).

Bloodworth, A. 2012. Global dynamics of critical metals or What's so special about critical metals? [In:] Conference "Critical minerals for the clean energy and high technology industries 2012 and beyond - the EU perspective”. Copenhagen, Denmark, May 21 2012. [Online] Available at: http://critical-minerals-2012.geus.dk/presentations/1-2_Andrew_Bloodworth GEUS-20120521.pdf [Accessed: September 25, 2016].

Bolewski, A. ed. 1991-1994. Encyklopedia surowców mineralnych. Vol. 1-4. Kraków: CPGSMiE PAN (in Polish). Buchert et al. 2012 - Buchert, M., Manhart, A., Bleher, D. and Pingel, D. 2012. Recycling critical raw materials from waste electronic equipment. Darmstadt: Öko-Institut, 80 p. 
Canalys 2016. Media alert: Over 1.5 billion smart phones to ship worldwide in 2016. [Online] Available at: https://www.canalys.com/newsroom/media-alert-over-15-billion-smart-phones-ship-worldwide-2016 [Accessed: September 25, 2016].

Cossu, R. and Williams, I.D. 2015. Urban mining: Concepts, terminology, challenges. Waste Management 45, pp. 1-3.

Ericsson 2016. Ericsson Mobility Report. On the Pulse of Networked Society. June 2016. Stockholm: Ericsson, 32 p. [Online] Available at: http://www.ericsson.com/mobility-report [Accessed: September 25, 2016].

Gartner 2016. Worldwide Device Shipments to Grow 1.9 Percent in 2016, While End-User Spending to Decline for the First Time. [Online] Available at: http://www.gartner.com/newsroom/id/3187134 [Accessed: September 25, 2016].

GUS 2016. Informacja o sytuacji społeczno-gospodarczej kraju w 2015 roku. Warszawa: Główny Urząd Statystyczny, 93 p. (in Polish).

Hagelüken, C. 2013. Recycling of technology metals from electronics. A good opportunity - and a complex challenge [In:] Conference “Closing the Loop”. Scherpenzeel, Netherlands, October 2 2013. [Online] Available at: http://www.p-plus.nl/resources/articlefiles/ClosingtheLoopNL2013-10Hagelueken.pdf [Accessed: September 25, 2016].

Halada, K. 2008. Urban mining. [Online] Available at: http://www.nims.go.jp/genso/lecture/0ej00700000030pw-att/0ej00700000034on.pdf[Accessed: September 25, 2016].

IDC 2015. Worldwide Smartphone Market Will See the First Single-Digit Growth Year on Record, According to IDC. Online] Available at: http://www.idc.com/getdoc.jsp?containerId=prUS40664915 [Accessed: September 25, 2016].

IDC 2016. Despite Polish Smartphone Market Reaching Saturation, Huawei Recorded Strong Growth in Q1 2016. [Online] Available at: http:/www.idc.com/getdoc.jsp?containerId=prCEMA41289616 [Accessed: September 25, 2016].

MIEP 2016. Raport o funkcjonowaniu system gospodarki zużytym sprzętem elektrycznym i elektronicznym 2015 roku. Warszawa: Main Inspectorate of Environmental Protection, 24 p. (in Polish).

Mueller et al. 2015 - Mueller, S.R., Wäger, P.A., Widmer, R. and Williams, I.D. 2015. A geological reconnaissance of electrical and electronic waste as a source for rare earth metals. Waste Management 45, pp. 226-234.

Nieć et al. 2014 - Nieć, M., Galos, K. and Szamałek, K. 2014. Main challenges of mineral resources policy in Poland. Resources Policy 42, pp. 93-103.

Pietrzyk-Sokulska, E. 2016. Recykling jako potencjalne źródło pozyskiwania surowców mineralnych z wybranych grup odpadów. Zeszyty Naukowe Instytutu Gospodarki Surowcami Mineralnymi i Energia PAN 92, pp.141-162 (in Polish).

Smakowski et al. eds. 2015 - Smakowski, T., Galos, K., Lewicka, E. eds. Bilans gospodarki surowcami mineralnym Polski i świata 2013. Warszawa: PIG-PIB, 1169 p. (in Polish).

Sullivan, D.E. 2006. Recycled Cell Phones - A Treasure Trove of Valuable Metals. USGS Fact Sheet $2006-3097$. Denver, Colorado, USA, 4 p. [Online] Available at: http://pubs.usgs.gov/fs/2006/3097/fs2006-3097.pdf [Accessed: September 25, 2016].

Wikipedia 2016. List of countries by number of mobile phones in use. [Online] Available at: https://en.wikipedia.org/wiki/List_of_countries_by_number_of_mobile_phones_in_use [Accessed: September 25 2016].

Willner, J. and Fornalczyk, A. 2012. Złom elektroniczny jako źródło metali szlachetnych. Przemysł Chemiczny 91(4), pp. 517-522 (in Polish). 


\title{
METALE W ZUŻYTYCH TELEFONACH KOMÓRKOWYCH - NOWE WYZWANIE DLA GOSPODARKI SUROWCAMI MINERALNYMI
}

\author{
Słowa kluczowe
}

zużyte telefony komórkowe, recykling metali, zasoby metali

\section{Streszczenie}

Na świecie rośnie bardzo dynamicznie sprzedaż telefonów komórkowych (w 2015 roku osiągnęła poziom 1,92 mld sztuk). Wiąże się to także z gwałtownym wzrostem liczby używanych na świecie telefonów komórkowych (szacuje się że jest ich ok. 7 mld sztuk). Cykl życia telefonów komórkowych jest krótki (zwykle około 18 miesięcy), co jest związane głównie ze zmieniającą się modą, postępem technicznym oraz konkurencją. Dlatego rośnie liczba nieużywanych aparatów przechowywanych w domach - na świecie ocenia się ich liczbę na około 14 mld. W Polsce liczbę tę szacuje się na około $100 \mathrm{mln}$ sztuk (włączając w to ok. $30 \mathrm{mln}$ smartfonów). Telefony komórkowe zawierają - w zróżnicowanych ilościach - cały szereg cennych metali takich jak: $\mathrm{Cu}, \mathrm{Ni}, \mathrm{Ag}, \mathrm{Au}, \mathrm{PMG}, \mathrm{Co}, \mathrm{Li}, \mathrm{Pb}, \mathrm{Sn}$, $\mathrm{Zn}, \mathrm{REE}, \mathrm{Ga}$, In, Fe, Cr, Nb, Ta, Ti. Koncentracja metali w telefonach komórkowych wielokrotnie przewyższa koncentrację tych pierwiastków w złożach pierwotnych.

Szacuje się, że składowane w polskich domach zużyte telefony komórkowe zawierają: około $1344 \mathrm{Mg} \mathrm{Cu}, 27 \mathrm{Mg} \mathrm{Ag}, 2,6 \mathrm{Mg} \mathrm{Au}, 1 \mathrm{Mg}$ Pd, około 4,3 Mg Nd, 0,8 Mg Pr, 454 Mg Co. Natomiast zużyte telefony komórkowe w skali świata zawierają: około 196 tys. $\mathrm{Mg} \mathrm{Cu}, 70$ tys. $\mathrm{Mg} \mathrm{Co}, 4$ tys. $\mathrm{Mg}$ $\mathrm{Au}, 400 \mathrm{Mg} \mathrm{Au}, 140 \mathrm{Mg} \mathrm{Pd}, 630 \mathrm{Mg}$ Nd oraz $126 \mathrm{Mg}$ Pr. Stwarza to zatem nowe wyzwania przed gospodarką surowcami mineralnymi odnośnie poszukiwań efektywnych dróg zagospodarowania zawartych w tych telefonach zasobów metali. Odzyskanie metali ze zużytych telefonów komórkowych zarówno w Polsce, jak i na świecie pozwoli bowiem na ograniczenie wydobycia kopalin ze złóż pierwotnych, co pozytywnie wpłynie na środowisko naturalne, a ponadto zmniejszy strumień istniejących odpadów. Poziom zbiórki zużytych telefonów komórkowych jest w Polsce bardzo niski, zapewne nie przekracza 1\%. Należy zatem wprowadzać nowe efektywne systemy odbioru telefonów komórkowych połączone na przykład z obowiązkiem przekazywania zużytego aparatu telefonicznego operatorowi sieci komórkowej przy uzyskiwaniu nowego aparatu. Ponadto należy finansować badania nad rozwojem efektywnej technologii odzysku metali ze zużytych telefonów komórkowych. 


\title{
METALS IN SPENT MOBILE PHONES (SMP) - \\ A NEW CHALLENGE FOR MINERAL RESOURCES MANAGEMENT
}

\author{
Keywords
}

spent mobile phone, metal recycling, metal resources

Abstract

The world sales of mobile phones is growing very dynamically (in 2015 reaching a level of approx. 1.92 billion units). The number of worldwide mobile phones in use is also rapidly increasing (it is estimated that their amount is approx. 7 billion units). The life cycle of a mobile phone is short (commonly approx. 18 months), which is mainly associated with the changing trends, technical progress and competition. This is the reason why a growing number of spent mobile phones (SMP) is stored in homes - the number of SMP worldwide is estimated at approx. 14 billion units. In Poland, estimated number of SMP stored in homes is approx. 100 million units (including approx. 30 million spent smartphones). Mobile phones contain various quantities of valuable metals such as: $\mathrm{Cu}, \mathrm{Ni}, \mathrm{Ag}$, $\mathrm{Au}, \mathrm{PMG}, \mathrm{Co}, \mathrm{Li}, \mathrm{Pb}, \mathrm{Sn}, \mathrm{Zn}, \mathrm{REE}, \mathrm{Ga}$, In, Fe, Cr, Nb, Ta, Ti. The concentration of such metals in mobile phones often times exceeds the concentration of these elements in primary deposits.

It is estimated that SMPs stored in Polish homes contain approx. 1,344 Mg Cu, $27 \mathrm{Mg} \mathrm{Ag}$, 2.6 Mg Au, $1 \mathrm{Mg} \mathrm{Pd}$, 4.3 Mg Nd, 0.8 Mg Pr, and $454 \mathrm{Mg}$ Co. Worldwide, SMPs contain at least 196,000 Mg Cu, 70,000 Mg Co, 4,000 Mg Ag, 400 Mg Au, 140 Mg Pd, 630 Mg Nd, 126 Mg Pr. This creates new challenges for mineral resources management, especially regarding introduction of new effective directions of utilization of metals recovered from SMPs. The recovery of metals from SMPs will in fact decrease the extraction of minerals from primary deposits, which will have a positive impact on the environment, and reduce the stream of existing e-wastes. The collection of SMPs in Poland is currently at a very low level, probably not exceeding $1 \%$. It is therefore necessary to introduce new efficient SMP collection systems combined, for example, with the obligation to transfer the spent telephone to the operator while obtaining a new one. The authors suggest the need to begin research on the development of efficient technologies of metal recovery from spent mobile phones. 